\title{
MISSION STATEMENTS AND FINANCIAL PERFORMANCE IN LATIN-AMERICAN FIRMS
}

\author{
Julián David CORTÉS-SÁNCHEZ, Liliana RIVERA \\ School of Management, Universidad del Rosario, Bogotá, Colombia \\ E-mails: julian.cortess@urosario.edu.co (corresponding author); myriam.rivera@urosario.edu.co
}

Received 28 January 2019; accepted 29 March 2019

\begin{abstract}
Mission statements (MSs) are one of the most widespread managerial practices. However, a deeper understanding of the relationship between MS's characteristics and firms' financial performance is still necessary. The vast majority of the research on this topic has been performed on companies of the global north, rather than the global south. The present study addresses this literature gap through a qualitative and quantitative analysis of MS characteristics (i.e., keywords and readability) for Latin-American firms and their relationship to financial performance. The content analysis of the MS was conducted using Voyant Tools, the MS readability was measured through six readability indices (i.e., FI, FRE, FKGL, SMOG, CL and ARI) and the relationship between MS readability and financial performance was determined using regression analysis (i.e., OLS). The results of the content analysis suggest differences among industries and an international convergence toward isomorphism regarding key terms. The results of the quantitative analysis revealed a positive relationship between MS readability and return on assets (ROA) and return on equity (ROE). These results suggest a positive relation of the MS on a company's long-term financial performance, highlighting the importance of having a readable MS.
\end{abstract}

Keywords: mission statements, content analysis, financial performance, Latin America.

JEL Classification: M16, M21, G10, G20.

\section{Introduction}

Strategic planning activities in organizations demand substantial human and financial resources. The average time-consuming in strategic planning activities is between four to five months and cost an average of 25,000 persondays per billion dollars of revenue (Pfeffer and Sutton 2006). Therefore, strategic planning activities should be selective and efficient in the adoption of the practices that have shown positive effects during and after their implementation. Mission statements (MSs) are one of the most widespread managerial practices used in strategic planning worldwide. An MS expresses what a firm is and should be, and is regarded as the critical starting point for almost every firm's major strategic initiative (Bart et al. 2001, Godoy-Bejarano and Tellez-Falla 2017). The reported benefits of MSs are: providing a sense of the organization's direction and purpose; focusing the allocation of organizational resources; communicating effectively with important internal and external stakeholders; and describing the values of the organization that will guide and inspire organizational members (Bartkus et al. 2000, Desmidt et al. 2011). Certainly, "firms need to develop a strategy and establish clear goals and objectives, but the benefit of condensing and/or publicizing the firm's strategy in a mission statement is not fully understood" (Bartkus et al. 2006). Desmidt et al. (2011) addressed the calls in the literature for a closer examination of the relationship between developing a MS and the consequent improvement in financial performance, and found that there is a small positive relationship between MSs and financial measures of organizational performance, but the strength of the relationship is influenced by operational decisions. This is in line with the findings of Bart et al. (2001), who concluded that an MS, to be successful, must

Copyright (C) 2019 The Authors. Published by VGTU Press.

This is an Open Access article distributed under the terms of the Creative Commons Attribution License (http://creativecommons.org/licenses/by/4.0/), which permits unrestricted use, distribution, and reproduction in any medium, provided the original author and source are credited.. 
be based on a proper rationale, include sound content, be organizationally aligned, and drive behavioral change.

Thus, a successful MS should be readable and understandable. A high-quality MS provides orientation for stakeholders in general and facilitates the decision-making process (Godoy-Bejarano and Tellez-Falla 2017). Furthermore, Desmidt (2016) found that individual acceptance of the MS can be partially explained by the cognitions and attributes of the message recipients, employee perceptions regarding the sender, and the degree of ambiguity. Despite their importance, little research has been undertaken to determine the characteristics of MSs that are most likely to produce specific organizational benefits. Additionally, most of the research on this issue has been conducted in the US, Europe, and Asia, with very few studies in other regions such as Latin America. Thus, this study aims to contribute to our knowledge of the MS-financial performance relationship by evaluating the effects of MS readability on the financial performance of companies in Latin America.

This study analyzes the impact of MS content and readability on a firm's financial performance using regression models based on data from 121 Latin-American companies. The companies' MSs are analyzed using content analysis software to identify common words and structures, while readability is measured quantitatively using various readability indices to determine the level of difficulty in terms of comprehension. A regression analysis was used to establish the relationship between MS readability and several financial performance measures (i.e., sales variation, net profit, net margin, net profit variation, EBITDA, EBITDA variation, EBITDA margin, total assets, ROE, and ROA). The results that were obtained have important managerial and theoretical implications, and are a response to the call of Desmidt et al. (2011) to determine which MS characteristics induce specific organizational benefits, and thus influence the effectiveness of MSs.

The rest of the paper is organized as follows. Section 1 presents a literature review, Section 2 presents the methodology, including data selection and the methods used for analysis, and Section 3 presents a discussion of the results and their theoretical and managerial implications. Section 4 presents conclusions and recommendations for future studies.

\section{Literature review}

The literature review was focused on seminal studies focused on the question of a business's purpose (i.e., MS development) and empirical studies aimed at disentangling the relationship between MSs and organizational performance. The seminal studies established pathways for the decision-making process after considering the purpose of an organization, its long-term goals, and how to achieve them (Jones 1960). Later, a number of empirical studies analyzed MS content (Pearce and David 1987), MS readability (Daniel 1986), and the relationship between MSs and organizational performance (Robinson and Pearce 1983). This review focuses on MS content, MS readability, and the relationship between MSs and financial performance in privately owned organizations.

Of the seminal studies, Jones (1960) affirmed that longterm goals (i.e., increasing the welfare of an organization's beneficiaries) and the means of achieving those goals should sustain the framework of the decision-making process in any organization. In the same year, Theodore Levitt gave birth to the strategy school of MSs by addressing the problem of narrow, although vague, business definitions and describing the role of the CEO in establishing the style, direction, and goals of a firm (Levitt 1960). Later, Peter Drucker reframed the MS development process by addressing two key questions: "What is our business?" and "What should it be?" (Drucker 1973).

Encouraged by these theoretical discussions, several empirical studies were conducted in the 1980s analyzing the content of MSs and its relationship to business performance. Pearce (1982) identified eight key components of any MS: target customers and markets; identification of principal products or services; geographic domain; core technologies; concern for survival, growth and profitability; corporate philosophy; corporate self-concept; and the company's desired public image. Drawing on this framework, Daniel (1986) found that firms should make their MS as readable and assertive as possible to improve their organizational image and to use its precision and simplicity to communicate it to their employees, thereby enabling them to follow the desired path towards accomplishing their goals in the future (Bartkus et al. 2000). Pearce and David (1987) found that Pearce's (1982) strategic elements such as corporate philosophy, self-concept, and concern for public perception were essential building blocks for a comprehensive MS. Additionally, Campbell (1989) proposed a framework to define the MS based on four components, purpose, strategy, values, and standards and behaviors, and also found that firms with an MS outperformed those without an MS (see Figure 1).

Since the late 1990s, Christopher Bart and colleagues have pursued a prolific research agenda on the relationship between MSs and organizational performance. At first glance, Baetz and Bart (1996) amplified the framework first outlined by Pearce (1982) into ten MS categories/components (i.e., financial objectives, non-financial objectives, values, beliefs, philosophies, definition of success, number one priority, specific product definition, specific market definition, basis of competition, number of stakeholders mentioned, and stakeholders identified) and proposed a formula for a typical MS that should integrate both financial 
"Why the company exists"

$\begin{gathered}\text { Purpose company's } \\ \text { strategy for } \\ \text { achieving its } \\ \text { purpose" }\end{gathered}$
Standards and behaviors

"The policies and behavior patterns that guide the company operates"

Figure 1. What is a mission statement? (source: Campbell 1989 , p. 4)

and non-financial objectives, the company's definition of success and values, and a mention to the stakeholders.

In the 1970s, the field of planning presented seminal conclusions on the positive relationship between MSs and organizational performance (Burt 1978, Karger and Malik 1975), followed by a critical appraisal of the marginal benefits of formal planning (Robinson and Pearce 1983). Specifically, in relation to MSs and performance, Bart (1997a) found a small relationship between MSs and multiple financial indicators (i.e., return on sales, return on assets (ROA), annual sales variation, and annual profit variation), but a significant positive relationship between MSs and firms' innovative behavior/practices (Bart 1996). In addition, Bart (2001) argued that MSs are valuable planning tools for measuring and reporting on intellectual capital components within organizations.

In addition, several studies have found both positive perceptions by CEOs (Analoui and Karami 2002) and a measurably positive relationship between MS comprehensiveness (e.g., by integrating several components of Pearce's (1982) framework) and performance in several regions and countries such as US, Japan, and Europe (Bartkus et al. 2000, Hirota et al. 2010, Sidhu 2003, Williams 2008). In the case of Turkish small and medium-sized enterprises (SMEs), Duygulu et al. (2016) concluded that three of Pearce's (1982) MS components (i.e., survival, growth, and profit; philosophy and value; and public image) served as independent variables that explained high levels of organizational performance. In relation to MS readability, Sattari et al. (2011) claimed that the MSs of US companies were not particularly readable, and in many cases required the reading skills of a university graduate. Similarly, Fitzgerald and Cunningham (2016) found a moderate positive correlation between patents granted and the number of the Pearce's (1982) mission statement components in Irish university technology transfer offices.

One of the few studies from the South, to our knowledge, was conducted by Godoy-Bejarano and Tellez-Falla (2017) on a sample of firms from Colombia. They found that the effect on asset turnover dominates when a MS compels good asset management practices within the Mission Power (i.e., use of positive language, orientation to financial goals, readability, and asset endowment).

A few studies debated the relevance of MS to performance, yet this statement was either reversed at the conclusions, overshadowed by further studies conducted by the same author or anchored to small samples and to a single context/country. Ireland and Hirc (1992) argued that companies might not develop a MS because it would demand high amount of resources, it has an academic purpose, or it would unveil secret information about the company. Nevertheless, they further accepted that MS improve communication and motivation. Later, Bart (1997b) cited statements from senior managers from leading US companies on why MSs might not be developed such as wrong mission, development process dissatisfaction, and no influence over behavior. Overall, "the vast majority [of MSs] are not worth the paper they are written on and should not be taken with any degree of seriousness" (Bart 1997b, p. 12), yet from 1997 onwards, Bart and colleagues pursued a research agenda that supported the importance of MSs for organizations in terms of planning, performance, and influence on behavior, as previously mentioned. O'Gorman and Doran (1999) found no correlation between MSs and performance, but their sample was limited to 64 Irish firms.

To synthetize 20 years of research, Desmidt et al. (2011) conducted, to our knowledge, the first meta-study on the relationship between MSs and financial performance, arguing that there was a small positive relationship. However, it is important to note that their meta-analysis examined only 14 studies, hence their conclusion, "[is it] time to shelve the discussion? Not necessarily” (Desmidt et al. 2011, p. 479).

More recent research has focused on providing a more comprehensive view between MSs and its implementation. Macedo et al. (2016) found that organizational commitment acts as mediating variable between MSs and organizational performance in non-profit sector organizations. Marimon et al. (2016) argue that there is a difference between the existence of a MS and its internalization among employees; in consequence they propose a construct for the internalization of the mission statement. Similarly, Rey and Bastons (2018) proposes a holistic MSs model which include motivational and dynamic dimensions instead of merely the traditional formal dimension (e.g. stating the MS in a web page).

The literature reviewed thus far has been focused on the North (i.e., the US and Europe) and Asia, but few studies, to our knowledge, have been conducted in Latin America, other than that of Godoy-Bejarano and Tellez-Falla (2017), and companies other than SMEs (i.e., public companies) have not been studied in detail. The use of readability indices has been controversial, especially the use of the Gunning fog index (FI) (Gunning and Mueller 1981), as researchers 
have stated that commonly used words in business have been pinpointed as complex to read, and few studies have been conducted in this regard in the South. In addition, no studies have provided open access to the datasets used for the purposes of either replication or triangulation, despite constant demands from the academic community (Aarts et al. 2015). With that in mind, the aim of this study is to conduct a content analysis of MSs to determine the effect of MS readability on financial performance in companies in Latin America. Furthermore, the dataset used in this study will be made available for public access.

\section{Methodology}

\subsection{Data}

To identify a suitable sample of companies from Latin America, we examined one of the most influential publications on business and economy in the region, América Economía. América Economía Intelligence publishes a series of rankings, among which is ranking de las 500 mayores empresas de América Latina en 2014 (ranking of 500 major companies in Latin America in 2014), hereafter "the ranking." This ranking was used as the basis for our analysis. All of the data used in this study is accessible via the following link: https://goo.gl/iGBL1z or using the following QR code (Figure 2).

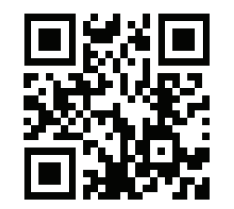

Figure 2. Dataset QR code (source: the author)

\subsection{Financial performance indicators}

The ranking queries for the financial data into the companies, official entities and customs office, and Economatica (i.e., an investment analysis system used by thousands of analysts at numerous entities worldwide for investigating balance sheet, stock market, investment funds and government bond analysis. It displays financial data for the 1,000 largest companies listed on the stock exchange (América Economía n.d.). Data on financial indicators were available for 2012-2013. Table 1 lists the financial indicators displayed in the ranking.

\subsection{Mission statements}

The MSs were obtained from each company's official website, and were presented either under a specific tab or in the strategic/corporate plans/reports section. Only sections labeled "mission," "our mission," or "mission statement" were considered, as in Desmidt et al. (2011). Sections such
Table 1. Financial indicators used by América Economía in ranking 500 Latin-American companies (source: América Economía 2014)

\begin{tabular}{|l|}
\hline Sales 2012 US\$ \\
\hline Sales 2013 US\$ \\
\hline Sales variation $13 / 12(\%)$ \\
\hline Net profit 2012 US\$ \\
\hline Net profit 2013 US\$ \\
\hline Net profit variation $13 / 12(\%)$ \\
\hline EBITDA 2012 US\$ \\
\hline EBITDA 2013 US\$ \\
\hline EBITDA variation $13 / 12(\%)$ \\
\hline Total assets 2013 US\$ Mill. \\
\hline Total equity 2013 US\$ Mill. \\
\hline Employees \\
\hline Exports 2013 US\$ Mill. \\
\hline ROE (\%) 2013 \\
\hline ROA (\%) 2013 \\
\hline Net margin (\%) 2013 \\
\hline EBITDA margin (\%) 2013 \\
\hline Exports as a \% of sales 2012 \\
\hline Listed on the stock exchange $(\mathrm{Y}=$ Yes; $\mathrm{N}=\mathrm{No})$ \\
\hline Ownership (P = Private; E = Public) \\
\hline
\end{tabular}

as "our values," "purpose," "vision," or "what we believe in," for instance, were not considered. The majority of the MSs were available in Spanish (86\%), but MSs in Portuguese (2\%) and English (12\%) were also gathered.

We included companies listed in the ranking that had a full set of financial indicators and had published an MS on their website, resulted in a total sample of 121 companies. Table 2 presents an overview of the companies included in the sample in terms of economic sector, country, stock exchange listing, and type of ownership. Table 3 presents the descriptive statistics for the various financial indicators.

\section{Methods}

\subsection{Content analysis}

Voyant Tools was used to conduct the MS content analysis. This program is web-based and open-access (Sinclair and Rockwell 2015). The content analysis involved the quantification and visualization of the most frequently mentioned terms and their relationships with other key terms. The following redundant words were removed: misson (mission), empresa (enterprise), organización(es) (organization(s)), and compañía (company). 
Table 2. Company overview - economic sector, country, stock exchange listing, and type of ownership (source: América Economía 2014)

\begin{tabular}{|l|c|}
\hline \multicolumn{1}{|c|}{$n=121$} & \\
\hline Sector & \% of the sample \\
\hline Energy & 19 \\
\hline Retail & 15 \\
\hline Food & 8 \\
\hline Mining & 7 \\
\hline Iron \& Steel/Metallurgy & 7 \\
\hline Telecommunications & 5 \\
\hline Automotive/Auto Parts & 4 \\
\hline Drinks/Liqueurs & 4 \\
\hline Manufacturing & 4 \\
\hline Oil/Gas & 4 \\
\hline Air transportation & 2 \\
\hline Pulp/Paper & 2 \\
\hline Multisector & 2 \\
\hline Road transport & 2 \\
\hline Cement & 2 \\
\hline Petrochemicals & 2 \\
\hline Ports/Airports & 2 \\
\hline Sanitary & 2 \\
\hline
\end{tabular}

\begin{tabular}{|l|c|}
\hline Agro-industry & 1 \\
\hline Entertainment & 1 \\
\hline Logistics & 1 \\
\hline Media & 1 \\
\hline Chemistry/Pharmacy & 1 \\
\hline Health \\
\hline Country \\
\hline BRA & 39 \\
\hline MEX & 36 \\
\hline CHI & 11 \\
\hline ARG & 7 \\
\hline COL & 4 \\
\hline CH/BR & 1 \\
\hline ECU & 1 \\
\hline PAN & 1 \\
\hline PER & 1 \\
\hline URU & 1 \\
\hline Listed on the stock exchange \\
\hline Yes & 74 \\
\hline No & 26 \\
\hline Ownership & 88 \\
\hline Private & 12 \\
\hline Public & \\
\hline
\end{tabular}

Table 3. Descriptive statistics for the financial indicators (source: América Economía 2014)

\begin{tabular}{|c|c|c|c|c|c|c|}
\hline & $\begin{array}{l}\text { Sales } 2012 \text { US\$ } \\
\quad \text { (millions) }\end{array}$ & $\begin{array}{l}\text { Sales } 2013 \text { US\$ } \\
\quad \text { (millions) }\end{array}$ & $\begin{array}{c}\text { Sales variation } \\
13 / 12(\%)\end{array}$ & $\begin{array}{l}\text { Net profit } 2012 \\
\text { US\$ (millions) }\end{array}$ & $\begin{array}{l}\text { Net profit } 2013 \\
\text { US\$ (millions) }\end{array}$ & $\begin{array}{c}\text { Net profit } \\
\text { variation } 13 / 12 \\
(\%)\end{array}$ \\
\hline Sum & $953.226,60$ & $30.620,30$ & - & - & & - \\
\hline Mean & $7.877,91$ & $7.691,08$ & $-2 \%$ & 510,35 & 336,02 & $-65 \%$ \\
\hline Median & $3.205,10$ & $3.135,30$ & $-1 \%$ & 182,90 & 183,20 & $-9 \%$ \\
\hline SD & $17.942,82$ & $17.304,23$ & $11 \%$ & $1.297,09$ & $1.661,63$ & $655 \%$ \\
\hline Max & $137.694,60$ & $130.150,30$ & $43 \%$ & $10.225,10$ & $9.992,30$ & $1582 \%$ \\
\hline \multirow[t]{2}{*}{ Min } & $1.307,10$ & $1.333,10$ & $-32 \%$ & $-1.482,70$ & $-13.006,10$ & $-6612 \%$ \\
\hline & $\begin{array}{l}\text { EBITDA } 2012 \\
\text { US\$ (millions) }\end{array}$ & $\begin{array}{l}\text { EBITDA } 2013 \\
\text { US\$ (millions) }\end{array}$ & $\begin{array}{c}\text { EBITDA variation } \\
13 / 12(\%) \\
\end{array}$ & $\begin{array}{c}\text { Total assets } 2013 \\
\text { US\$ (millions) }\end{array}$ & $\begin{array}{c}\text { Total equity } 2013 \\
\text { US\$ (millions) }\end{array}$ & ROE (\%) 2013 \\
\hline Sum & - & - & - & $1.525 .895,90$ & $568.483,30$ & - \\
\hline Mean & $2.124,29$ & $2.071,63$ & $15 \%$ & $12.610,71$ & $4.698,21$ & $10 \%$ \\
\hline Median & 559,30 & 576,20 & $1 \%$ & $4.442,60$ & $1.906,60$ & $10 \%$ \\
\hline SD & $8.529,56$ & $7.588,10$ & $99 \%$ & $34.466,51$ & $14.797,24$ & $24 \%$ \\
\hline Max & $88.123,70$ & $75.880,40$ & $846 \%$ & $321.423,50$ & $149.122,30$ & $131 \%$ \\
\hline \multirow[t]{2}{*}{ Min } & $-188,90$ & 36,20 & $-287 \%$ & 553,70 & $-14.167,70$ & $-122 \%$ \\
\hline & ROA (\%) 2013 & $\begin{array}{c}\text { Net margin (\%) } \\
2013\end{array}$ & $\begin{array}{l}\text { EBITDA margin } \\
(\%) 2013\end{array}$ & & & \\
\hline Sum & - & - & - & & & \\
\hline Mean & $5 \%$ & $7 \%$ & $21 \%$ & & & \\
\hline Median & $4 \%$ & $6 \%$ & $16 \%$ & & & \\
\hline SD & $5 \%$ & $9 \%$ & $15 \%$ & & & \\
\hline Max & $25 \%$ & $55 \%$ & $84 \%$ & & & \\
\hline Min & $-8 \%$ & $-11 \%$ & $2 \%$ & & & \\
\hline
\end{tabular}

\footnotetext{
Note: sales, net profit, EBITDA, assets and equity amounts are in millions of US dollars.
} 


\subsection{Readability indices}

Readability indices are used to determine the level of comprehension difficulty of written material (Flesch 1948) and to avoid needless complexities in the mechanics of writing (Gunning 1969). Studies conducted in the fields of business, management, and accounting have examined the readability of annual reports and its effect on analysts' earnings forecasts (Lehavy et al. 2011, Li 2008, Subramanian et al. 1993). The overall finding is that greater readability is related to better performance, clear disclosure, and greater levels of understanding in business and finance communications (Linsley and Lawrence 2007, Rennekamp 2012).

The most widely used index for readability in business and finance is Robert Gunning's (1969) FI (Clark et al. 1990, Flory et al. 1992, Kaminski and Clark 1987, Karlinsky and Koch 1983, Lo et al. 2017, Loughran and McDonald 2014). The FI estimates the number of years of schooling a person needs to understand a given text. Sydserff and Weetman (1999) criticized readability indices because of their focus on words and sentences regardless of the text as a whole, and thus their inappropriateness for evaluating adult-directed technical accounting narratives. Therefore, MS readability was calculated using the FI and five other indices: 1) Flesch Reading Ease (FRE) and 2) Flesch Kincaid Grade Level (FKGL), both of which are used to test the readability of technical documents for the armed forces (Kincaid et al. 1975); 3) Simple Measure of Gobbledygook (SMOG) (McLaughlin 1969), which is used to test the readability of health-care material and is consistent in relation to text in Spanish, English, and French, with a few limitations
(Contreras et al. 1999); 4) Coleman-Liau (CL) (Coleman and Liau 1975), which is used to test the readability of textbooks in the public school system; and 5) Automated Readability Index (ARI) (Senter and Smith 1967), which is used to test the readability of technical documents for the armed forces. Figure 3 presents the formula used for calculating each index.

\subsection{Effect of mission statement readability on financial performance}

First, bivariate correlation analysis was conducted among the six readability indices to identify internal correlations. Second, regression analysis was conducted to assess the effect of MS readability on financial performance in terms of sales variation, net profit variation, EBITDA variation, total assets, total equity, ROE, ROA, net margin, and EBITDA margin. Third, logistic regression analysis was conducted to assess the effect of MS readability on the presence of firms in the stock market. Finally, each regression was tested for robustness. The Stata 15.1 software package was used for all analyses.

\section{Results}

\subsection{Content analysis}

A total of 3,980 words were analyzed. The average number of words per sentence was 33.2. The ten most used words were: clientes (clients/customers) (43), nuestros/ nuestra (our) (42/24), calidad (quality) (29), productos (products) (29), accionistas (stakeholders) (22), desarrollo

\begin{tabular}{|c|c|c|}
\hline Index & Calculation formula & Interpretation \\
\hline FI & $0.4(A S L+P H W)$ & $\begin{array}{l}\text { Years of formal education a person needs to understand the } \\
\text { text on the first reading (e.g., } 17 \text { is equivalent to a college } \\
\text { graduate) }\end{array}$ \\
\hline FRE & $206.835-1.015($ words $/$ sentences $)-84.6($ syllables $/$ words $)$ & Scale of $0-100$. A higher score means greater readability \\
\hline FKGL & $0.39($ words $/$ sentences $)+11.8($ syllables $/$ words $)-15.59$ & $\begin{array}{l}\text { American school grade a person needs to be in to } \\
\text { comprehend the text (e.g., } 7.5 \text { means that the text should be } \\
\text { understandable for a person who is in } 7 \text { th or } 8 \text { th grade, or } \\
12-14 \text { years old) }\end{array}$ \\
\hline SMOG & 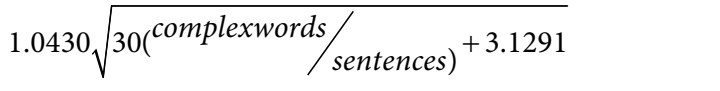 & Approximates the age needed to understand the text \\
\hline CL & $5.89($ characters $/$ words $)-0.3($ sentences $/$ words $)-15.8$ & $\begin{array}{l}\text { American school grade needed to be in to comprehend the } \\
\text { text }\end{array}$ \\
\hline ARI & $4.71($ characters $/$ words $)+0.5($ words $/$ sentences $)-21.43$ & Approximates the age needed to understand the text \\
\hline
\end{tabular}

Note: ASL (Average Sentence Length) = number of words in a text of at least 100 words divided by the number of sentences. PHW (Percent Hard Words) = number of words that contain more than three syllables (non-proper nouns, combinations of easy or hyphenated words, or two-syllable verbs that become three syllables by adding "-es" or "-ed" endings) divided by the total number of words. The variable complexwords means words with three or more syllables.

Figure 3. Readability indices and their calculation formulas (source: Webpagefx 2018) 
(development) (22), energía (energy) (22), servicios (services) (19), necesidades (needs) (17), and colaboradores (partners) (14). The ten least used words were sector (sector) (8), crear (to create) (7), generando (generating) (7), proveedores (suppliers) (7), rentabilidad (profitability) (7), respeto (respect) (7), suministro (supply) (7), ambiental (environmental) (6), buscamos (searching for) (6), confiable (reliable) (6), and consumidores (consumers) (6).

To visualize the relationships between the most used terms, Figure 4a presents a collocation graph (i.e., a network wherein links between key words, shown in blue, and collocated words, shown in orange, are identified). The three key terms highlighted were "clients," "our," and "quality." "Clients" and "our" were closely related to each other, and to "suppliers," "stakeholders," "partners," "consumers," and "expectations," whereas "quality" was related to "products," "respect," "responsibility," and "security." Based on Pearce and David's (1987) and Robinson and Pearce's (1983) frameworks for a comprehensive MS, firms from Latin America emphasized six key components: 1) specification of target customers and markets, for example, "clients," "consumers," and their "expectations"; 2) identification of principal products/services, for example, "quality," "products," and "energy"; 3) commitment to survival, growth, and profitability, for example, references to the firm's "shareholders"; 4) company philosophy, for example, explicit statements of values such as "respect" for employees and shareholders, and the long-term relationships being built; 5) company self-concept, for example their social "responsibility" in relation to the community and the environment; and 6) public image, for example, guaranteeing the "quality" of their services/products and occupational "security" for their employees. Table 4 presents the MS of Daimler, a firm from the automotive sector in Mexico, as an example of an MS in which the six key components are identified.

A content analysis by sub-groups was also conducted. Figure $4 \mathrm{~b}$ shows that firms that climbed the ranking from 2012 to 2013 based on sales variation (right side) used key terms in their MS such as "clients/customers," "quality," "products," and "communities." Conversely, firms that fell in the ranking (left side) used terms such as "people" relatively more often. Figure $4 \mathrm{c}$ shows that the most commonly used term in the energy sector was "development" (i.e., social, environmental, and career orientation), in the food sector it was "quality," in the mining sector it was "development," and in the retail sector it was "clients/customers" and "products". Figure $4 \mathrm{~d}$ shows that the most commonly used term in Brazil and Chile was "clients/customers," whereas in Mexico it was "clients/customers" and "products." In Mexico, the term "stakeholders" was also commonly used, as was the term "development" in Chile. Figure 4e shows that firms listed on the stock exchange used more terms such

Table 4. Example of an MS including the six key components proposed by Pearce and David (1987) and Robinson and Pearce (1983) (source: DAIMLER 2016)

\begin{tabular}{|c|c|}
\hline Daimle MS & $\begin{array}{l}\text { Translated sections of the Daimler MS and their corresponding } \\
\text { key components }\end{array}$ \\
\hline \multirow{12}{*}{$\begin{array}{l}\text { Inventamos el automóvil y los vehículos comerciales y } \\
\text { nos apasiona su futuro. Somos pioneros en la industria } \\
\text { automotriz. Estamos orgullosos y comprometidos en dar } \\
\text { forma al futuro de una transportación segura y sostenible por } \\
\text { medio de tecnologías innovadoras y productos de alta calidad. } \\
\text { Rebasamos las expectativas de nuestros clientes con marcas } \\
\text { fascinantes, automóviles premium, los mejores vehículos } \\
\text { comerciales de su clase y servicios financieros excelentes. Nos } \\
\text { esforzamos por lograr un crecimiento sostenible y rentable } \\
\text { entre los líderes de la industria, como un equipo enfocado a la } \\
\text { excelencia. Aspiramos a convertirnos en la primera opción a } \\
\text { elegir como socio de negocio. Vivimos nuestra responsabilidad } \\
\text { con el medio ambiente y la comunidad. Nos apegamos a } \\
\text { estrictos estándares de ética. Estamos inspirados, facultados } \\
\text { y guiados por nuestros valores centrales: pasión, respeto, } \\
\text { integridad y disciplina. Valoramos la diversidad y buscamos } \\
\text { desarrollar todo nuestro potencial como un equipo global. }\end{array}$} & 1) Specification of target customers and markets: \\
\hline & [...] "We are pioneers in the automotive industry". \\
\hline & 2) Identification of principal products/services: \\
\hline & "[...] We invent the automobile and commercial vehicles" \\
\hline & $\begin{array}{l}\text { 3) Commitment to survival, growth, and profitability: "[...] We } \\
\text { strive for sustainable and profitable growth among industry } \\
\text { leaders as a team focused on excellence. We aspire to become the } \\
\text { first option to choose as a business partner." }\end{array}$ \\
\hline & 4) Company philosophy: \\
\hline & $\begin{array}{l}\text { "[...] We adhere to strict ethical standards. We are inspired, } \\
\text { empowered and guided by our core values: passion, respect, } \\
\text { integrity and discipline". }\end{array}$ \\
\hline & 5) Company self-concept: \\
\hline & $\begin{array}{l}\text { "[...] We live our responsibility to the environment and the } \\
\text { community." }\end{array}$ \\
\hline & 6) Concern for public image: \\
\hline & $\begin{array}{l}\text { "[...] We value diversity and seek to develop our full potential as } \\
\text { a global team." }\end{array}$ \\
\hline & $\begin{array}{l}\text { "[...] We are proud and committed to shaping the future of safe } \\
\text { and sustainable transportation through innovative technologies } \\
\text { and high-quality products." }\end{array}$ \\
\hline
\end{tabular}


as "clients/customers," "products," "quality," "stakeholders," and "community" than unlisted firms. Figure $4 \mathrm{f}$ shows that publicly owned firms used more terms such as "sustainable," "social," and "environment" than privately owned firms.

From an international perspective, Babnik et al. (2014) highlighted five key terms in the MSs of Slovenian firms: "people," "provide," "development," "customers," and "environment." There were several similarities with the key MS terms used by firms in Latin America, such as "clients/customers," "development," and "partners," whereas "environmental" was one of the least used terms in Slovenia. Duygulu et al. (2016) reported similar findings, as the most frequently used terms among SMEs in Turkey were commitment to survival, growth, and profitability, and identification of the firm's principal products/services and philosophy, with the exception of specification of target customers and markets as in Turkey it was the second last. Therefore, a convergence toward isomorphism in MS is emerging internationally. On the one hand, Duygulu et al. (2016) argued that MSs are becoming increasingly similar as a result of institutional and environmental pressures that influence what MSs should or should not contain. On the other hand, Bart (2001) highlighted the willingness of firms to publish their MSs on the Internet, thereby making them available for academic or other purposes, such as benchmarking methodologies to identify best practices, which are then adopted by other firms.

a) Overall analysis

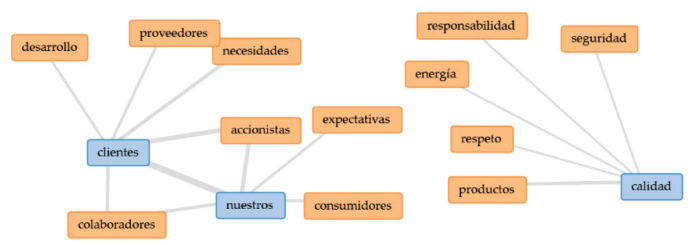

c) By sectors (In order left to right: Energy; Food; Mining; Retail).

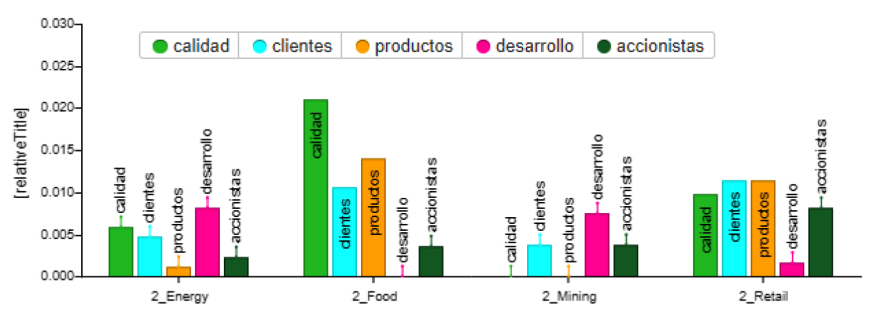

e) Presence (left) or absence (right) in the stock market

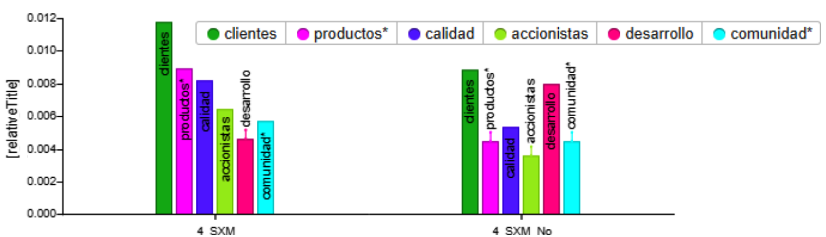

\subsection{Effect of mission statement readability on financi- al performance}

The mean scores on the various indices reveal that, on average, the MSs have a very low readability score (i.e., they are difficult to read and understand). Looking at the SMOG, the age needed to understand the MSs that were analyzed was, on average, more than 17 years. For instance, the MS of the Mexican company Organización Soriana had a SMOG score of 30.3 because it consisted of a single sentence of 54 words, with 28 (52\%) complex words and 2.67 syllables per word. Only seven companies (5\%) had a single-digit SMOG score. Looking at the FRE index, 77 (63\%) of the MS scores were negative on the $0-100$ scale. To check this anomaly, the FRE index was compared with the other indices. The results revealed a high degree of correlation among most of the readability indices (see Table 5). However, there was a significant negative correlation between the FRE index and the other indices, as the FRE index is measured on a scale of $0-100$, therefore a higher score means higher readability, while the other scales are measured in terms of either school grade or age, therefore a higher score means lower readability. Tabachnick and Fidell (2001, p. 84) suggest that variables that are highly correlated (e.g., 0.7 or more) should not be included in the same analysis. The FRE index was considered as an independent variable in relation to readability, as it allows for a wider assessment

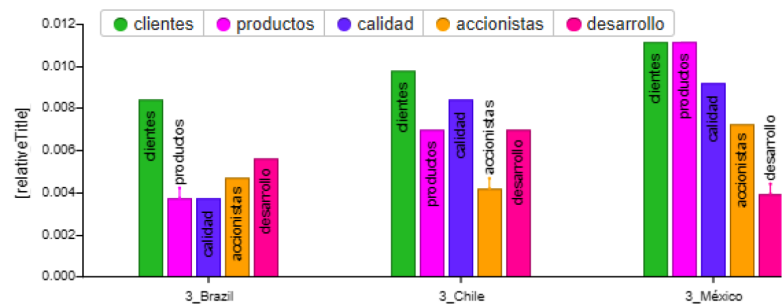

f) Privately (left) or publicly (right) owned

b) Firms falling in the ranking (left) vs. Firms climbing in the ranking (right).

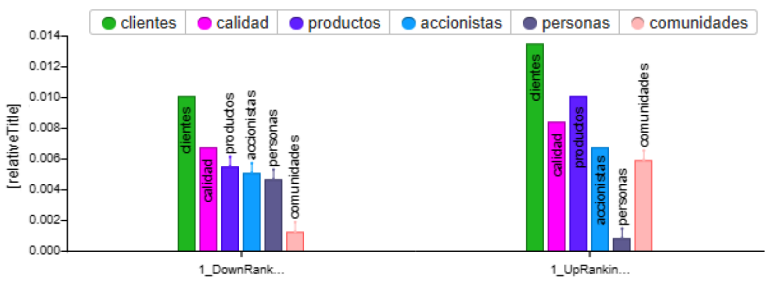

d) By country (In order left to right: Brazil; Chile; Mexico).

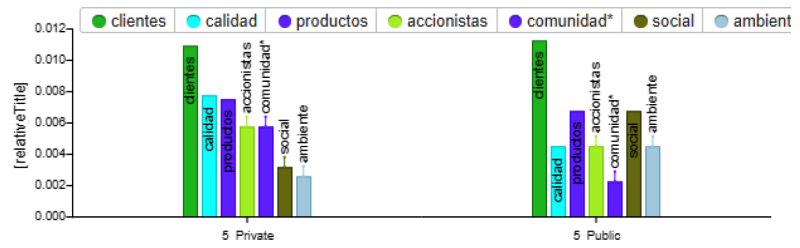

Figure 4. Content analysis findings (source: Firms' official websites and Voyant Tools' software) 
of readability rather than just grades or years of schooling, and it is significantly correlated with the other five indices.

A regression analysis was conducted to determine the effect of MS readability as measured by the FRE index (independent variable) on financial performance (dependent variables) as measured by sales variation, net profit variation, EBITDA variation, total assets, total equity, ROE, ROA, net margin, and EBITDA margin. Standard regression analysis was used to explore the relationship between one continuous dependent variable and a number of independent variables or predictors. Standard regression analysis is conducted in the case of only one continuous predictor variable and continuous dependent variable. Tables 6 and 7 show the results of the analysis. The FRE index predicted only $\operatorname{ROE}(F=13.12, p=0.0004)$ and $\operatorname{ROA}(F=4.35, p=$ 0.0391 ) significantly. FRE explained $10 \%$ of the variance in ROE and $3 \%$ of the variance in ROA. FRE predicted low variance in both ROE and ROA scores, despite the significance.

A logistic regression analysis was conducted to determine the effect of MS readability as measured by the FRE index (independent variable) on firms' presence in or absence from the stock market (see Table 8). Logistic regression is used to model dichotomous outcome variables which allow to testing models to predict categorical outcomes with two or more categories. In this study, the presence of firms in the stock exchange market is a binary dependent variable that is outcome variable. A test of the model with one predictor was not statistically significant $x^{2}(1, \mathrm{~N}=121)=$ $2.02, p=.15$. The FRE index explained $2.4 \%$ of either the presence in or absence from the stock market. A robustness test of each regression model revealed no differences from

Table 5. Correlations between readability indices (source: the author)

\begin{tabular}{|c|c|c|c|c|c|c|c|c|}
\hline & Mean & $\mathrm{SD}$ & FRE & FKGL & FI & SMOG & $\mathrm{CL}$ & ARI \\
\hline \multirow{2}{*}{ FRE } & -10.4 & 25.4 & 1 & & & & & \\
\hline & & & & & & & & \\
\hline \multirow{2}{*}{ FKGL } & 21.23 & 5.9 & $-.849^{* *}$ & 1 & & & & \\
\hline & & & .000 & & & & & \\
\hline \multirow{2}{*}{ FI } & 24.82 & 6.78 & $-.738^{* *}$ & $.923^{* *}$ & 1 & & & \\
\hline & & & .000 & .000 & & & & \\
\hline \multirow{2}{*}{ SMOG } & 17.51 & 4.9 & $-.671^{* *}$ & $.929^{* *}$ & $.933^{* *}$ & 1 & & \\
\hline & & & .000 & .000 & .000 & & & \\
\hline \multirow{2}{*}{ CL } & 17.3 & 3.7 & $-.615^{* *}$ & $.284^{* *}$ & $.191^{*}$ & .098 & 1 & \\
\hline & & & .000 & .002 & .035 & .283 & & \\
\hline \multirow{2}{*}{ ARI } & 18.07 & 7.05 & $-.709^{* *}$ & $.944^{* *}$ & $.886^{* *}$ & $.924^{* *}$ & $.277^{* *}$ & 1 \\
\hline & & & .000 & .000 & .000 & .000 & .002 & \\
\hline \multicolumn{9}{|c|}{$n: 121$} \\
\hline
\end{tabular}

Note: ${ }^{\star *}$ correlation is significant at the $0.01 ;{ }^{\star}$ correlation is significant at the 0.05 )

Table 6. Regression results using the FRE index as the independent variable and sales variation, net profit variation, EBITDA variation, and total assets as the dependent variables (source: the author)

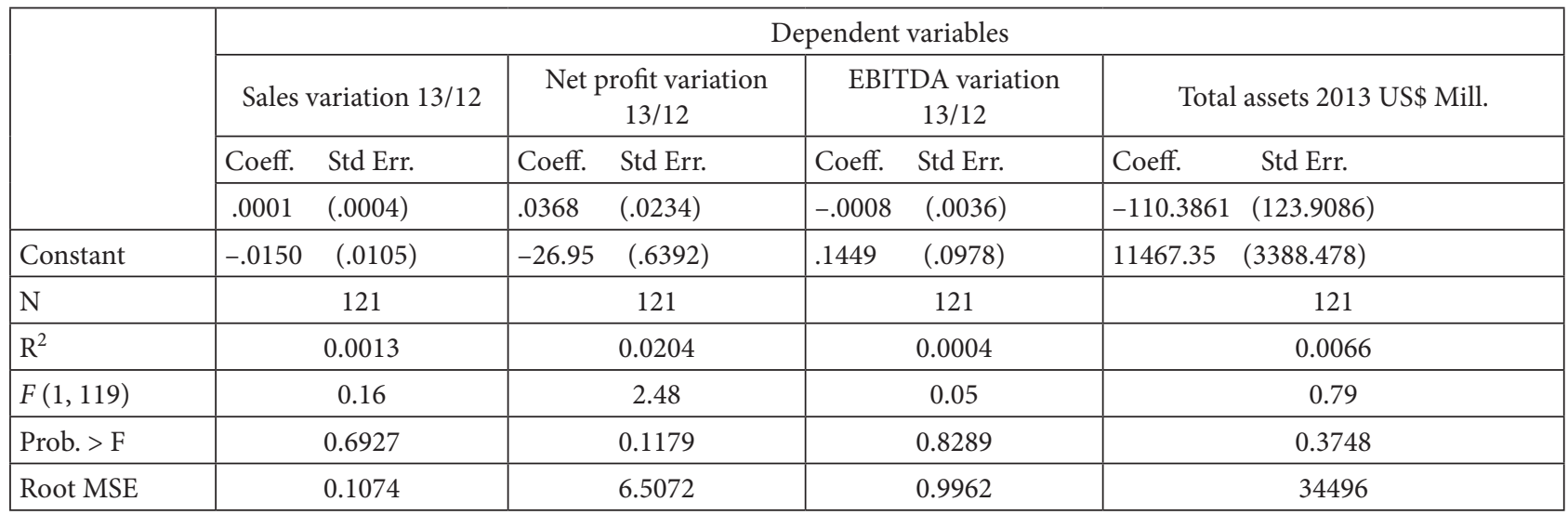

Note: ${ }^{\star} \mathrm{p}<.05$. 
Table 7. Regression results using the FRE index as the independent variable and total equity, ROE, ROA, net margin, and EBITDA margin as the dependent variables (source: the author)

\begin{tabular}{|c|c|c|c|c|c|c|c|}
\hline & \multicolumn{7}{|c|}{ Dependent variables } \\
\hline & $\begin{array}{c}\text { Total equity } 2013 \\
\text { US\$ Mill. }\end{array}$ & ROE 2013 & ROA 2013 & \multicolumn{2}{|c|}{ Net margin 2013} & \multicolumn{2}{|c|}{ EBITDA margin 2013} \\
\hline & Coeff. $\quad$ Std Err. & Coeff. Std Err. & Coeff. Std Err. & Coeff. & Std Err. & Coeff & Std Err. \\
\hline & $-12.07 \quad(53.36)$ & $.0029 \quad(.0008)$ & $.0004 \quad(.0004)$ & .0005 & $(.0003)$ & .0007 & $(.0005)$ \\
\hline Constant & $4573.16 \quad(1459.28)$ & $.1293(.0222)^{\star}$ & $.0513 \quad(.0049)^{\star}$ & .0792 & $(.0092)$ & .2137 & $(.0149)$ \\
\hline $\mathrm{N}$ & 121 & 121 & 121 & & 121 & & 121 \\
\hline $\mathrm{R}^{2}$ & 0.0004 & 0.0993 & 0.0353 & & 0.0213 & & 0.0156 \\
\hline$F(1,119)$ & 0.05 & 13.12 & 4.35 & & 2.59 & & 1.89 \\
\hline Prob. $>$ F & 0.8214 & 0.0004 & 0.0391 & & 0.1105 & & 0.1716 \\
\hline Root MSE & 14856 & 0.22656 & 0.0496 & & 0.0939 & & 0.1518 \\
\hline
\end{tabular}

Note: ${ }^{\star} \mathrm{p}<.05$.

the ordinary least squares regression models in terms of statistically significant results.

Table 8. Logistic regression results using the FRE index as the independent variable and firms' presence in or absence from the stock market as the dependent variable (source: the author)

\begin{tabular}{|l|c|c|c|c|c|c|}
\hline & B & E.T. & Wald & gl & Sig. & $\operatorname{Exp(B)}$ \\
\hline FRE & -0.01 & 0.01 & 1.976 & 1 & 0.2 & 0.988 \\
\hline Constant & 0.922 & 0.22 & 18.25 & 1 & 0 & 2.514 \\
\hline
\end{tabular}

\section{Discussion}

ROE and ROA are used to compare the profitability of a company with that of other firms in the same market (Gómez-Betancourt et al. 2012). ROA is the ratio of earnings to total assets, and is a long-term indicator of the firm's efficiency of asset usage in generating revenue (Godoy-Bejarano and Tellez-Falla 2017). ROE is the ratio of earnings to total equity, and is a long-term indicator of the profitability of the firm in relation to shareholder equity. MSs influence a company's stakeholders and, in particular, employees' and clients' behaviors (Bartkus et al. 2006). In fact, a better MS makes outsiders' and employees' perspectives regarding the company more positive, creating a more favorable reputation and leading to better performance from employees and the attraction of new customers. Workers with a clear understanding of the company's MS will be more efficient in their use of a given amount of assets and equity, leading to increased productivity and improvements in long-term financial indicators, given that changes in productivity will need some time to be reflected in the financial indicators. The improved performance of the employees leads to better use of the company's assets and equity, thereby increasing productivity and optimizing the ROA and ROE. This result is in line with results from previous studies on the relationship between MSs and ROA
(Bart 1997b, Bartkus et al. 2006, Hirota et al. 2010). As for the relationship between MSs and ROE, to the best of the authors' knowledge, this is the first study to analyze this relationship. Murphy et al. (1996) showed that ROE is positively correlated with ROA because both indicators have the same numerator but different denominators (equity and assets), because equity is always less than or equal to assets. Thus, this positive relationship is expected.

Another relevant fact is the well-documented relationship between ROE and the price-to-book (PB) ratio of a firm's stock. The PB ratio is the ratio between the company's market price and its book value. A high PB ratio reflects high growth and performance expectations for the future (Higgins 2000). According to corporate finance theory, $\mathrm{ROE}$ is a variable that explains other variables such as the expected growth rate of the firm's $\mathrm{PB}$ ratio and earnings per share (Berk and DeMarzo 2017). Damodaran (2002) also found through a regression approach that the $\mathrm{PB}$ ratio is a function of ROE in several national markets (the US, Greece, Brazil, Portugal, and India). A high ROE is closely related to market expectations about the firm's ability to maintain and improve its financial performance in the future. As noted earlier, a better MS improves stakeholders' perspectives regarding the company, creating a more favorable market reputation, which helps to explain the positive relationship between MSs and ROE.

The results indicate a positive impact of the MS on a company's long-term financial performance, which highlights the importance of having a simple but powerful MS. This can be explained from different perspectives. Firstly, even though the MS is normally crafted by top executives or third parties, its objective is common among companies. "Both mission and vision statements work as a unifying force as they enable different people in an organization to work towards a common objective... which becomes the prime force behind peak performance" (Ahmed et al.2013). Unification of stakeholders leads to better performance in 
an organization because the workforce is directed towards the efficient use of the company's resources toward the achievement of the company's goals and objectives. In this sense, better employee performance leads to better use of the company's assets and equity, increasing productivity, and thus increasing ROA and ROE. This result is in line with the findings of previous studies: by fostering better employee alignment and developing organizational capabilities, financial performance is enhanced (Ouakouak 2017).

Moreover, since the MS is one of the seven elements of the strategic planning construct in a company (Baker 2003), it is possible that the significant results that were obtained regarding the relationship between $\mathrm{ROA} / \mathrm{ROE}$ and MSs may be mediated by a well-implemented strategy. In fact, Rhyne (1986) noted that "firms with planning systems more closely resembling strategic management theory were found to exhibit superior long-term financial performance both relative to their industry and in absolute terms," while Orpen (1994) claimed that "small firms which engaged in strategic planning performed better financially than those which failed to do so."

An MS can also include an emphasis on the value system that is established within an organization. "Specifying a set of values in the mission may attract a more motivated, ethical employee" (Bartkus et al. 2006), leading to better performance and greater ROA. This is because there is a higher probability of better use of the company's assets and less possibility of lost working hours.

It is important to note that although the relationship between MS characteristics and ROE has not previously been addressed in the literature, $\mathrm{ROE}$ is by far the most popular measure of financial performance among investors and senior managers (Higgins 2000). Duygulu et al. (2016) concluded that there is a significant positive relationship between having an MS and shareholder equity, as the average ROE for firms with MSs was $16.1 \%$ compared to $9.7 \%$ for those without MSs.

ROE is the product of profit margin ${ }^{1}$, asset turnover ${ }^{2}$, and financial leverage ${ }^{3}$, and these three measures capture the major elements of a company's financial performance (Fabozzi et al. 2008). In general, companies' ROE is similar, but the combinations of profit margin, asset turnover, and financial leverage that produce the end result vary widely (Higgins 2000). For example, firms with high profit margins tend to have a low ROA because they are capital intensive, and those with low profit margins tend to have a high ROA (Fabozzi et al. 2008). Meanwhile, the difference between ROA and ROE is financial leverage ${ }^{4}$. Unlike the profit mar-

\footnotetext{
$1 P M=$ Net Income $/$ Sales

$2 A T=$ Sales $/$ Total Assets

$3 F=$ Total Assets/Equity

4 Note that $R O A=P M \times A T$, so $R O E=R O A \times F L$.
}

gin and asset turnover, where more is generally preferred to less, decision-making in relation to financial leverage is difficult, because this is not something that management necessarily wants to maximize (Berk and DeMarzo 2017). It is important to note that ROA and financial leverage tend to be inversely related, because companies with low ROA generally employ more debt financing (Higgins 2000). Thus, ROE represents a complex equilibrium between a firm's income, assets, and liabilities.

Finally, a tenuous relationship between MSs and financial performance, specifically ROA, has also been found by Bart (1997a) and Hirota et al. (2010). Godoy-Bejarano and Tellez-Falla (2017) also found that MS Power affected asset turnover, an indicator that is closely related to ROA. This study was unable to provide support for either Williams's (2008) findings on the effects of MSs on firms' revenues and profits or Bart's (1997a) findings on the effects of MSs on return on sales, annual sales variation, and annual profit variation. The findings of Sidhu (2003) and Duygulu et al. (2016) related to financial performance (i.e., sales growth compared with competitors, business capital, profit, dividends, and extra-financial sources) were based on a survey of CEOs/owners, instead of data from either balance sheets or profit and loss reports, and are not supported by the findings of this study. It is important to note that the studies discussed in this section focused on the comprehensiveness of MSs rather than their readability, with the exception of the study of Godoy-Bejarano and Tellez-Falla (2017). Overall, the findings of this study support the small positive relationship between MSs and financial performance that was found in Desmidt et al.s (2011) meta-study.

\section{Conclusions}

The results of both the qualitative and quantitative analyses provided some important insights and implications. The qualitative analysis showed that the keywords used in the MSs of the sampled firms were similar to those used by firms in various other countries. Therefore, it can be concluded that there is an international convergence toward isomorphism in terms of MSs. The quantitative analysis revealed a significant positive relationship between MS readability and ROA and ROE. This supports the evidence in the literature regarding the relationship between ROA and MS characteristics, but also extends this relationship to include ROE, which has not previously been reported.

Qualitative results of the content analysis showed some relevant results for the Latin American firms. Beyond the observed tendency of isomorphism among MSs in Latin America and worldwide, some differences were identified. For example, the firms that climbed positions on Ranking of 500 Latin-American companies, based on sales variation between 2012 and 2013, used key terms in their MS such as "clients/customers," "quality," "products," and 
"communities." Conversely, firms that fell in the ranking used terms such as "people" relatively more often. An explicit mention towards "communities" rather than merely "people" in the MS may be related with better firm performance. Additionally, the relative frequency distribution of the main keywords varies widely according to a firm's sector, type of ownership or presence/absence in the stock market. This showed that while general key terms can be identified in the bulk of firms, their relative use responds to the enterprises' specific context and characteristics.

Quantitative results showed a positive impact of the MS on a company's long-term financial performance, which highlighted the importance of having a readable MS. Even though the relationship between ROA and ROE is wellknown, there are important implications with regard to the MS. First, ROA and ROE are long-term profitability indicators that describe the ratio between net profit and the firm's assets and equity, respectively. The results suggest that a more readable MS can help the company's workers and stakeholders to use assets and equity more efficiently to generate greater revenue for the company. A clear MS can enable outsiders and employees to adopt a more positive perspective toward the company, creating a more favorable reputation and leading to better performance by employees and the attraction of new customers. Thus, an effective MS can improve the company's long-term financial performance.

The open access dataset provided in this study, is a valuable tool for both researchers and practitioners. In the case of researchers, this dataset allows to conduct replication and triangulation studies, also, provides inputs for conducting national or regional studies. In the case of practitioners, it is a benchmarking resource for constructing a MS content differentiated from competitor's, and to compare the readability properties of any firm in order to improve them. Further studies using larger databases, including data collected over longer periods of time or related to SMEs, would be useful to test the consistency of the results obtained in this study. Additionally, further research is needed on the causality of the relationship between MSs and financial performance. Further studies are also needed to incorporate other financial performance measures such as those related to risk and market value. Timing issues arise because the firm's book value is backward looking, and earnings are focused on a single period. ROE is a measure of profitability, rather than a measure of risk, so it provides no indication of the risk that the company has taken to generate returns. Moreover, ROE measures the return on the shareholders' investment based on the book value of the shareholders' equity, not the market value.

Lastly, the FRE score of this manuscript is 22.6. Which means is well understood by university graduates. This is an acceptable score for our text, considering the decreasing readability of academic texts over time. For instance, in a large readability analysis of more than 700,000 abstracts, it was found that in $1960,14 \%$ of the text had a FRE below 0 . This number had risen to $22 \%$ in 2015 (Plavén-Sigray et al. 2017).

\section{Acknowledgments}

The authors would like to thank to the following research assistants for their valuable support (in alphabetical order): Camilo Flórez, Daniel Rincón, Daniela Burgos, David Flechas, Érika Valero, Estefanía Avellaneda, Francisco Cuesta, Ingrith Nathaly Abril, María Camila Avella, María Camila Cristancho, Stefanny Cano, and Valentina Sánchez. We also thank Geoff Whyte, MBA, from Edanz Group (www.edanzediting.com/ac) for editing a draft of this manuscript.

\section{References}

Aarts AA, Anderson JE, Anderson CJ, Attridge PR, Attwood A, Axt J, ... Zuni K (2015) Estimating the reproducibility of psychological science. Science 349 (6251). https://doi.org/10.1126/science.aac4716

Ahmed I, Zeeshan Shaukat M, Islam T (2013) Mission statements readability: an insight into Islamic banks. Journal of Islamic Accounting and Business Research 4 (2): 132-150. https://doi.org/10.1108/JIABR-04-2012-0019

América Economía (2014) Las 500 mayores empresas de América Latina https://goo.gl/rfkmJk

América Economía (n.d.) Metodología https://goo.gl/WBSXBx

América Economía (n.d.) Qué hacemos https://corporativo. americaeconomia.com/

Analoui F, Karami A (2002) CEOs and development of the meaningful mission statement. Corporate Governance: The International Journal of Business in Society 2 (3): 13-20. https://doi.org/10.1108/14720700210440044

Babnik K, Breznik K, Dermol V, Širca NT (2014) The mission statement: Organisational culture perspective. Industrial Management and Data Systems 114 (4): 612-627. https://doi.org/10.1108/IMDS-10-2013-0455

Baetz MC, Bart, CK (1996) Developing mission statements which work. Long Range Planning 29 (4): 526-533. https://doi.org/10.1016/0024-6301(96)00044-1

Baker GA (2003) Strategic planning and financial performance in the food processing sector. Review of Agricultural Economics 25 (2): 470-482. https://doi.org/10.1111/1467-9353.00150

Bart CK (1996) The impact of mission on firm innovativeness. International Journal of Technology Management 11 (3-4): 479-493.

Bart CK (1997a) Industrial firms and the power of mission. Industrial Marketing Management 26 (4): 371-383. https://doi.org/10.1016/S0019-8501(96)00146-0

Bart CK (1997b) Sex, lies, and mission statements. Business Horizons 40 (6): 9-18. https://doi.org/10.1016/S0007-6813(97)90062-8 
Bart CK (2001) Exploring the application of mission statements on the World Wide Web. Internet Research 11 (4): 360-368. https://doi.org/10.1108/10662240110402812

Bart CK, Bontis N, Taggar S (2001) A model of the impact of mission statements on firm performance. Management Decision 39 (1): 19-35. https://doi.org/10.1108/EUM0000000005404

Bartkus B, Glassman M, Mcafee B (2006) Mission statement quality and financial performance. European Management Journal 24 (1): 86-94. https://doi.org/10.1016/j.emj.2005.12.010

Bartkus B, Glassman M, Mcafee RB (2000) Mission statements: are they smoke and mirrors? Business Horizons 43 (6): 24-28. https://doi.org/10.1016/S0007-6813(00)80018-X

Berk J, DeMarzo P (2017) Corporate finance. London: Pearson.

Burt DN (1978) Planning and performance in Australian retailing. Long Range Planning 11 (3): 62-66. https://doi.org/10.1016/S0024-6301(78)80010-7

Campbell A (1989) Does your organisation need a mission? Leadership \& Organization Development Journal 10 (3): 3-9. https://doi.org/10.1108/EUM0000000001134

Clark GL, Kaminski PF, Brown G (1990) The readability of advertisements and articles in trade journals. Industrial Marketing Management 19 (3): 251-260.

https://doi.org/10.1016/0019-8501(90)90017-P

Coleman M, Liau T (1975) A computer readability formula designed for machine scoring. Journal of Applied Psychology 60: 283-284. https://doi.org/10.1037/h0076540

Contreras A, García-Alonso R, Echenique M, Daye-Contreras F (1999) The SOL formulas for converting SMOG readability scores between health education materials written in Spanish, English, and French. Journal of Health Communication 4 (1): 21-29. https://doi.org/10.1080/108107399127066

DAIMLER (2016) Nuestra misión https://www.daimler.com.co/ compania.php

Damodaran A (2002) Investment valuation. New York: John Wiley \& Sons.

Daniel SC (1986) Communication effectiveness of organizational mission statements. Journal of Applied Communication Research 14 (2): 108-118.

https://doi.org/10.1080/00909888609360308

Desmidt S (2016) The relevance of mission statements: analysing the antecedents of perceived message quality and its relationship to employee mission engagement MISSION Analysing the antecedents of. Public Management Review 18 (6): 894-917. https://doi.org/10.1080/14719037.2015.1051573

Desmidt S, Prinzie A, Decramer A (2011) Looking for the value of mission statements: A meta-analysis of 20 years of research. Management Decision 49 (3): 468-483. https://doi.org/10.1108/00251741111120806

Drucker P (1973) Management: task, responsibilities, practices. New York: Harper \& Row.

Duygulu E, Ozeren E, Işildar P, Appolloni, A (2016) The Sustainable strategy for small and medium sized enterprises: The relationship between mission statements and performance. Sustainability (Switzerland) 8 (7). https://doi.org/10.3390/su8070698

Fabozzi F, Peterson P, Polimeni R (2008) The complete CFO handbook: from accounting to accountability. New Jersey: John Wiley \& Sons.
Fitzgerald C, Cunningham JA (2016) Inside the university technology transfer office: mission statement analysis. The Journal of Technology Transfer 41 (5): 1235-1246. https://doi.org/10.1007/s10961-015-9419-6

Flesch R (1948) A new readability yardstick. Journal of Applied Psychology 32 (3): 221-233. https://doi.org/10.1037/h0057532

Flory SM, Phillips Jr TJ, Tassin MF (1992) Measuring readability: a comparison of accounting textbooks. Journal of Accounting Education 10 (1): 151-161. https://doi.org/10.1016/0748-5751(92)90022-W

Godoy-Bejarano JM, Tellez-Falla DF (2017) Mission power and firm financial performance. Latin American Business Review $18(3-4): 211-226$.

https://doi.org/10.1080/10978526.2017.1400389

Gómez-Betancourt G, López MP, Betancourt JB, Millán JO (2012) Estudio sobre el desempeño de las empresas familiares colombianas que cotizan en la bolsa de valores, frente a las empresas no familiares. Entramado 8 (1): 28-42.

Gunning R (1969) The fog index after twenty years. Journal of Business Communication 6 (2): 3-13. https://doi.org/10.1177/002194366900600202

Gunning R, Mueller D (1981) How to take the fog out of writing. Chicago: Dartnell Corporation.

Higgins R (2000) Analysis for financial management. New York: McGraw-Hill.

Hirota S, Kubo K, Miyajima H, Hong P, Park YW (2010) Corporate mission, corporate policies and business outcomes: evidence from Japan. Management Decision 48 (7): 11341153. https://doi.org/10.1108/00251741011068815

Ireland RD, Hirc MA (1992) Mission statements: importance, challenge, and recommendations for development. Business Horizons 35 (3): 34-42. https://doi.org/10.1016/0007-6813(92)90067-J

Jones M (1960) Evolving a Business Philosophy. Academy of Management Journal 3 (2): 93-98.

Kaminski PF, Clark GL (1987) The readability of sales training manuals. Industrial Marketing Management 16 (3): 179-184. https://doi.org/10.1016/0019-8501(87)90024-1

Karger DW, Malik ZA (1975) Long range planning and organizational performance. Long Range Planning 8 (6): 60-64. https://doi.org/10.1016/0024-6301(75)90027-8

Karlinsky SS, Koch BS (1983) Readability is in the mind of the reader. Journal of Business Communication 20 (4): 57-69. https://doi.org/10.1177/002194368302000409

Kincaid J, Fishburne R, Rogers R, Chissom B (1975) Derivation of new readability formulas (automated readability index, fog count, and flesch reading ease formula) for Navy enlisted personnel. Naval Air Station Memphis: Chief of Naval Technical Training. https://doi.org/10.21236/ADA006655

Lehavy R, Li F, Merkley K (2011) The effect of annual report readability on analyst following and the properties of their earnings forecasts. Accounting Review 86 (3): 1087-1115. https://doi.org/10.2308/accr.00000043

Levitt T (1960) Marketing myopia. Harvard Business Review July/August: 45-56.

Li F (2008) Annual report readability, current earnings, and earnings persistence. Journal of Accounting and Economics 45 (2-3): 221-247. https://doi.org/10.1016/j.jacceco.2008.02.003 
Linsley PM, Lawrence MJ (2007) Risk reporting by the largest UK companies: Readability and lack of obfuscation. Accounting, Auditing and Accountability Journal 20 (4): 620-627. https://doi.org/10.1108/09513570710762601

Lo K, Ramos F, Rogo R (2017) Earnings management and annual report readability. Journal of Accounting and Economics 63 (1): 1-25. https://doi.org/10.1016/j.jacceco.2016.09.002

Loughran T, Mcdonald B (2014) Measuring readability in financial disclosures. Journal of Finance 69 (4): 1643-1671. https://doi.org/10.1111/jofi.12162

Macedo IM, Pinho JC, Silva AM (2016) Revisiting the link between mission statements and organizational performance in the non-profit sector: The mediating effect of organizational commitment. European Management Journal 34 (1): 36-46. https://doi.org/10.1016/j.emj.2015.10.003

Marimon F, Mas-Machuca M, Rey C (2016) Assessing the internalization of the mission. Industrial Management \& Data Systems 116 (1): 170-187. https://doi.org/10.1108/IMDS-04-2015-0144

McLaughlin H (1969) SMOG Grading - a new readability formula. Journal of Reading 12 (8): 639-646.

Murphy GB, Trailer JW, Hill RC (1996) Measuring performance in entrepreneurship. Journal of Business Research 35: 15-23. https://doi.org/10.1016/0148-2963(95)00159-X

O'Gorman C, Doran R (1999) Mission statements in small and medium-sized businesses. Journal of Small Business Management 37 (4): 59-66.

Orpen C (1994) Strategic planning, scanning activities and the financial performance of small firms. Strategic Change 3 (1): 45-55. https://doi.org/10.1002/jsc.4240030106

Ouakouak M L, Ouedraogo N (2013) The mediating role of employee strategic alignment in the relationship between rational strategic planning and firm performance: A European study. Canadian Journal of Administrative Sciences/Revue Canadienne des Sciences de l'Administration 30 (3): 143-158. https://doi.org/10.1002/cjas.1259

Pearce II JA (1982) The company mission as a strategic tool. Sloan Management Review Spring/1982: 15-24.

Pearce II JA, David F (1987) Corporate mission statements: the bottom line. Academy of Management Executive 1 (2): 109115. https://doi.org/10.5465/ame.1987.4275821

Pfeffer J, Sutton R (2006) Hard facts, dangerous half-truths \& total nonsense: profiting from evidence-based management. Boston: Harvard Business School Publishing.

Plavén-Sigray P, Matheson G J, Schiffler BC, Thompson WH (2017) The readability of scientific texts is decreasing over time. ELife, 6, e27725. https://doi.org/10.7554/eLife.27725

Rennekamp K (2012) Processing fluency and investors' reactions to disclosure readability. Journal of Accounting Research 50 (5): 1319-1354. https://doi.org/10.1111/j.1475-679X.2012.00460.x

Rey C, Bastons M (2018) Three dimensions of effective mission implementation. Long Range Planning 51 (4): 580-585. https://doi.org/10.1016/j.lrp.2017.07.002

Rhyne L C (1986) The relationship of strategic planning to financial performance. Strategic management journal 7 (5): 423-436. https://doi.org/10.1002/smj.4250070504
Robinson RB JR, Pearce JA II (1983) The impact of formalized strategic planning on financial performance in small organizations. Strategic Management Journal 4 (3): 197-207. https://doi.org/10.1002/smj.4250040302

Sattari S, Pitt LF, Caruana A (2011) How readable are mission statements? An exploratory study. Corporate Communications: An International Journal 16 (4): 282-292. https://doi.org/10.1108/13563281111186931

Senter R, Smith E (1967) Automated readability index. WrightPatterson Air Force Base, Ohio: Aerospace Medical Research Laboratories.

Sidhu J (2003) Mission statements: Is it time to shelve them? European Management Journal 21 (4): 439-446. https://doi.org/10.1016/S0263-2373(03)00072-0

Sinclair S, Rockwell G (2015) Text analysis and visualization: making meaning count. In: A New Companion to Digital Humanities. https://doi.org/10.1002/9781118680605.ch19

Subramanian R, Insley RG, Blackwell, RD (1993) Performance and readability: a comparison of annual reports of profitable and unprofitable corporations. Journal of Business Communication 30 (1): 49-61. https://doi.org/10.1177/002194369303000103

Sydserff R, Weetman P (1999) A texture index for evaluating accounting narratives: An alternative to readability formulas. Accounting, Auditing \& Accountability Journal 12 (4): 459488. https://doi.org/10.1108/09513579910283503

Tabachnick B, Fidell L (2001) Using multivariate statistics. New York: Harper Collins.

Webpagefx (2018) Readability test tool https://www.webpagefx. com/tools/read-able

Williams LS (2008) The mission statement: a corporate reporting tool with a past, present, and future. Journal of Business Communication 45 (2): 94-119. https://doi.org/10.1177/0021943607313989

\section{APPENDIX}

\section{Abbreviations}

ARI: Automated Readability Index

ASL: Average Sentence Length

CL: Coleman-Liau

EBITDA: Earnings before Interest, Taxes, Depreciation and Amortization

FI: Fog Index

FKGL: Flesch Kincaid Grade Level

FRE: Flesch Reading Ease

MS: Mission statements

PHW: Percent Hard Words

ROA: Return on Assets

ROE: Return on Equity

SMOG: Simple Measure of Gobbledygook 